\section{Специальная тема выпуска: Ценности: трансмиссия и влияние на установки людей в разньх культурах}

\title{
ВСТУПИТЕЛЬНОЕ СЛОВО
}

\section{Уважаемые читатели журнала «Психология»!}

Вашему вниманию предлагается подборка статей научных сотрудников и аспирантов Международной научно-учебной лаборатории социокультурных исследований НИУ ВШЭ (МНУЛ СКИ) на тему «Ценности: трансмиссия и влияние на установки людей в разных культурах».

Спектр изучения ценностей в лаборатории довольно широк, и в данном выпуске отражены лишь некоторые направления наших исследований. В частности, мы исследуем влияние ценностей на предпринимательские намерения (П. Шмит и А.Н. Татарко), на социально-экономические установки и представления (Г. Цой, Н.М. Лебедева, А.Н. Татарко), на установки по отношению к мигрантам (В.А. Понизовский и Д.С. Григорьев). Особое внимание уделяется исследованию предикторов межпоколенных сходств и различий в ценностях, в частности, рели- гиозной идентичности, восприятию детско-родительской психологической близости и особенностям социокультурной среды (3.Х. Лепшокова, В.Н. Галяпина, Н.М. Лебедева и Д.И. Дубров).

Почти все наши исследования являются кросс-культурными и выполнены в двух и более культурах. В выпуске пять из шести статей основаны на сравнении результатов исследований в ряде культур и регионов. Два исследования (В.А. Понизовского и Д.С. Григорьева) выполнены с использованием базы данных Европейского социального исследования, остальные работы построены на базе полевых исследований сотрудников МНУЛ СКИ в областях Центральной России, Южного федерального округа, в республиках Северного Кавказа (Кабардино-Балкария и Северная ОсетияАлания). Кросс-культурный подход является инструментом выявления универсалий и культурной специфики в психологии человека, и все 
современные направления психологической науки в той или иной мере используют кросс-культурные сопоставления.

Надеемся, что данные статьи пробудят интерес к изучению ценностей как ядра культуры, их природы и механизма влияния на установки и поведение человека.

Н.М. Лебедева 